\title{
Radiological features of tension pneumoperitoneum
}

\author{
Dhiraj Joshi, Bhaskar Ganai
}

Department of Clinical Radiology, Brighton and Sussex University Hospitals NHS Trust, Brighton, East Sussex, UK

\section{Correspondence to} Dr Dhiraj Joshi, dhiraj.joshi62@gmail.com

Accepted 30 May 2015
CrossMark

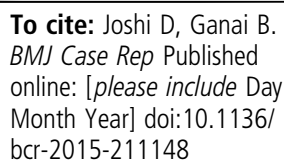

\section{DESCRIPTION}

An unconscious 35-year-old man with a history of recreational drugs intake presented with extremely distended and tympanic abdomen. Despite resuscitation, the patient was in shock.

A CT scan of the thorax and the abdomen demonstrated extensive pneumoperitoneum that was compressing the viscera into a central mass, which created an abdominal compartment-like syndrome. The inferior vena cava was compressed that decreased the venous return to heart (figure 1). The peritoneal gas extended into the mediastinum superiorly through the oesophageal hiatus and inferiorly into the scrotum through the inguinal canal (figure 2). The large pneumoperitoneum also decreased the thoracic volume by elevating the diaphragm (figure 3). The exact site of perforation could not be ascertained.

An urgent laparotomy restored the blood pressure and showed a large perforation of the lesser curvature of the stomach. Owing to the prolonged generalised ischaemia sustained prior to the laparotomy, the patient died in the intensive care 2 days later from multiorgan failure.

The features described are characteristic of tension pneumoperitoneum (TP). ${ }^{1}$ Most cases are iatrogenic. ${ }^{1}$ Spontaneous $\mathrm{TP}$ is rare and usually

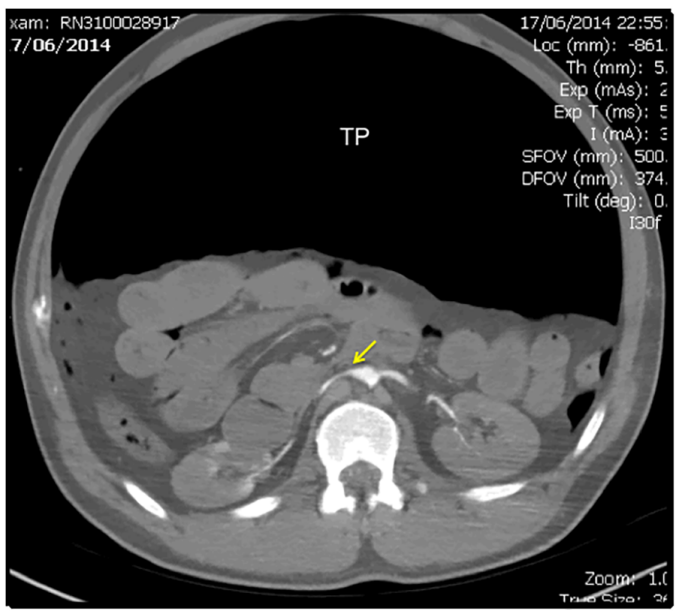

Figure 1 Tension pneumoperitoneum (TP). Intravenous contrast-enhanced CT scan of the abdomen in axial plane demonstrates a large pneumoperitoneum compressing the abdominal viscera into a central mass. Yellow arrow denotes the compressed inferior vena cava. The CT window has been optimised to demonstrate the pneumothorax as well as the soft tissue. caused by perforation of a hollow viscus. The exact mechanism is uncertain; however, it is believed that a flap valve at the site of perforation may be responsible. ${ }^{1}$ Just as in tension pneumothorax, a large bore needle should be placed into the peritoneal cavity once TP is recognised. ${ }^{2}$ Failure to do so may cause irreversible ischaemia to the vital organs as evident from the index case.

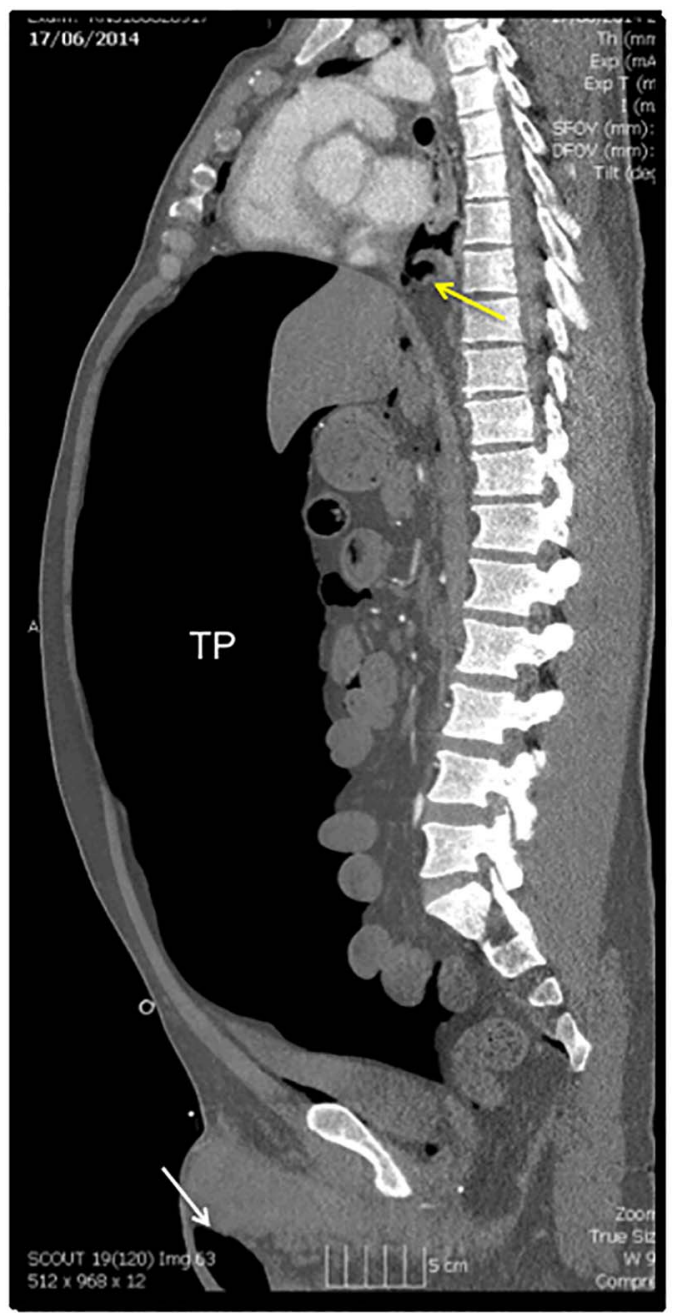

Figure 2 Tension pneumoperitoneum (TP). Intravenous contrast-enhanced CT scan of the abdomen in sagittal plane demonstrates a large pneumoperitoneum that extends superiorly into the mediastinum (yellow arrow) and inferiorly into the scrotum (white arrow). The CT window has been optimised to demonstrate the pneumothorax as well as the soft tissue. 


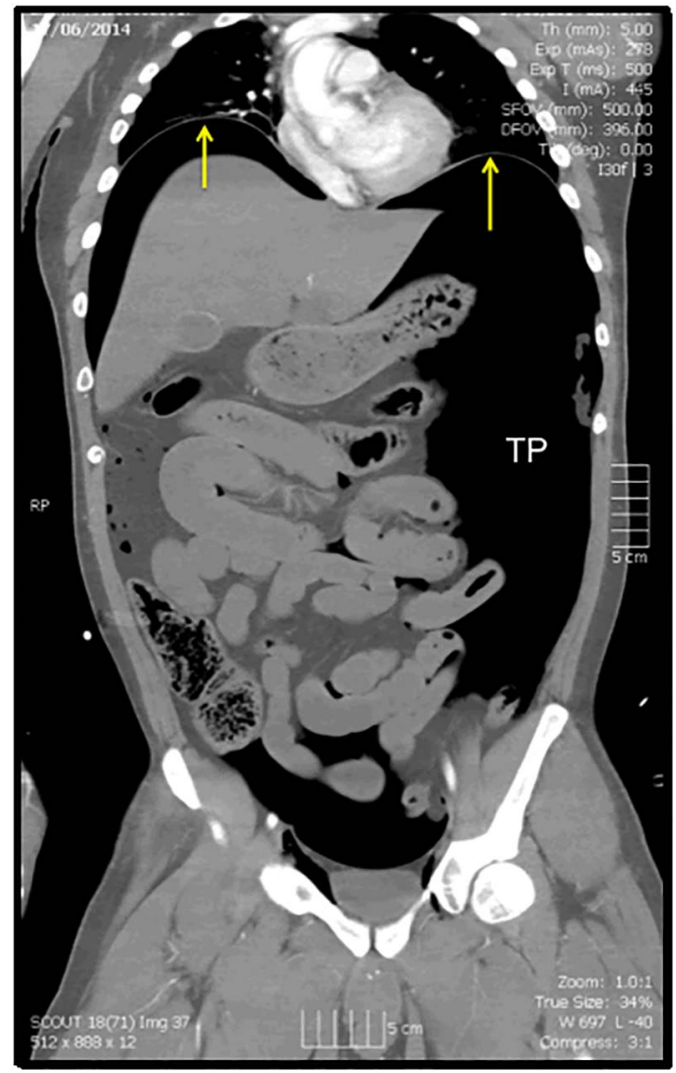

\section{Learning points}

- Characteristic CT appearance of tension pneumoperitoneum (TP) has been illustrated in three different planes of view.

- TP should be suspected in shocked patients who have severely distended and tympanic abdomen. A large bore needle can be inserted into the abdomen to alleviate the pressure and prevent irreversible end-organ ischaemia.

- After the patient's blood pressure has been restored, a CT scan of the abdomen may be obtained pending any operative intervention.

Contributors DJ prepared the manuscript and images. BG involved in the critical review.

Competing interests None declared.

Patient consent Obtained.

Provenance and peer review Not commissioned; externally peer reviewed.

\section{REFERENCES}

1 Chan SY, Kirsch CM, Jensen WA, et al. Tension pneumoperitoneum. West J Med 1996;165:61-4.

2 Akoglu H, Coban E, Guneysel O. Tension pneumoperitoneum complicated with tension pneumothorax in a patient with diaphragmatic eventration. BMJ Case Rep 2012;2012:pii: bcr0120125512.

Figure 3 Tension pneumoperitoneum (TP). CT scan of the abdomen in coronal plane demonstrates a large pneumoperitoneum that has caused marked elevation of the diaphragm (yellow arrows) and severely decreased volume of the thorax. The CT window has been optimised to demonstrate the pneumothorax as well as the soft tissue.

Copyright 2015 BMJ Publishing Group. All rights reserved. For permission to reuse any of this content visit

http://group.bmj.com/group/rights-licensing/permissions.

BMJ Case Report Fellows may re-use this article for personal use and teaching without any further permission.

Become a Fellow of BMJ Case Reports today and you can:

- Submit as many cases as you like

- Enjoy fast sympathetic peer review and rapid publication of accepted articles

- Access all the published articles

- Re-use any of the published material for personal use and teaching without further permission

For information on Institutional Fellowships contact consortiasales@bmjgroup.com

Visit casereports.bmj.com for more articles like this and to become a Fellow 